\title{
Notes
}

\section{A New Instrument for Interactive Virtual Plant Identification and Use}

\author{
Sandra B. Wilson ${ }^{1}$ and Helen E. Danielson ${ }^{2}$
}

ADDITIONAL INDEX WORDS. ornamentals, teaching gardens, native plants, agricultural education, distance education, active learning, web-technology

$\mathrm{N}$ umerous land-grant universities have established distance learning systems (Murphy, 1996), and it is generally agreed that educational programming for placebound students provides a needed scholastic opportunity for students, while strengthening undergraduate and graduate enrollment in agriculture (Tignor and Wilson, 1999). Within the University of Florida(UF), the Department of Environmental Horticulture offers undergraduate and graduate degrees at seven locations throughout the state. To ensure students have access to a sufficient variety of classes, many courses are delivered by distance education. The availability of distance education has significantly increased student enrollment while unifying lecture content, and minimizing duplication of faculty resources (Wilson and Thetford, 2003). However, the challenge of delivering hands-on laboratory portions of courses at remote locations still remains.

The utilization of web-based or video-enhanced horticulture in-

\footnotetext{
Department of Environmental Horticulture, Institute of Food and Agricultural Sciences, University of Florida.

Authors gratefully acknowledge Adam Nikolaidis for instructional design development and Laurie Mecca for digital photography. This project was funded by an Academic Technology Grant awarded by the University of Florida Center for Instructional Technology and Train ing Faculty Development Program and an Educational Mini-grant awarded by the College of Agriculture and Life Sciences, University of Florida/IFAS.

${ }^{1}$ Associate Professor, Indian River Research and Education Center, Fort Pierce, FL 34945. E-mail address: sbwilson@ifas.ufl.edu

${ }^{2}$ Graduate Research Assistant, PO Box 110670 Gainesville, FL 32611
}

struction has been incorporated in a variety of courses, including plant propagation (Gómez, 2004; Wilson and Thetford, 2003), plant identification (Anderson and Walker, 2003; Gilman, 1994; Sabota et al., 1995), and urban horticulture (Martin and Stutz, 1999). Shaw (1993) developed a dichotomous keying system that incorporated computer graphics to lead students through an interactive plant identification session. Starrett (2003) created a woody landscape plant walk through a portion of the University of Vermont campus using a scanned two-dimensional building map that is hyperlinked to the actual plant pictures. Sabota et al. (1995) developed an integrated location and information database for teaching plant identification and use, where a landscape plan of the Alabama A\&M University campus illustrates plant symbols that can be used to refer back to the database for plant characteristics. While these examples demonstrate a clear trend of the increased use of web- or computer-assisted instruction in horticulture courses, they often require specialized software or course packages and exclude any virtual aspect of actually walking through an area and "seeing" the plants.

Studies have shown that webbased learning can be as effective as live instruction. Anderson and Walker (2003) compared mean student scores for web-based and live plant identification tests and found no significant differences in student performance. Similarly, Kahtz (2000) found that his computer-assisted instruction program successfully served as a partial substitute for traditional woody plant identification laboratories with no detrimental effect on student achievement, regardless of cognitive learning style.

In an effort to illustrate landscape design principles and to facilitate access to plant material, a virtual, interactive tour of the Indian River Research and Education Center (IRREC) Teaching Garden was produced for online accessibility (Fig. 1). The 1-acre (0.4 ha) garden was constructed in 2001 and now displays over 229 plant species, of which about $60 \%$ are native to Florida (Wilson et al., 2004). To create a virtual tour of the teaching garden, a series of 30 panoramic digital photographs [300 pixels/inch (118.1 pixels $/ \mathrm{cm})]$ were taken 40 to $60 \mathrm{ft}$ (12.2 to 18.3 $\mathrm{m})$ apart throughout the garden using a high resolution Nikon Coolpix 5000 digital camera (Nikon, Melville, N.Y.) with a 360 One VR optic attachment (Kaidan, Feasterville, Pa.). Each digital image was loaded onto a computer and finished using Adobe Photoshop 7.0 (version 7.0.1; Adobe Systems, San Jose, Calif.). These images were then converted to QuickTime Pro 6.5 (Apple Computer, Cupertino, Calif.) video files using PhotoWarp 2.0 software (EyeSee 360, Pittsburgh). VR Worx 2.5 software(VR Toolbox, Pittsburgh) was used to stitch the movies together, enabling users to seamlessly navigate the movies and giving the feeling of taking a walk through the garden. As the viewer navigates through the garden, he or she can click on selected plants to generate a high resolution plant information data sheet. Using this web browser-based interface, seasonal plant characteristics, such as flower, fruiting, leaf structure, and form, can be viewed year-round.

The webpages for the virtual tour were created using Macromedia Dreamweaver MX 2004, (version 7.0.1; Macromedia, San Francisco). Separate templates were created for both the main site and the plant information sheets to ensure that informational and navigational items would remain consistent when creating new pages, allowing for a balance of facility and flexibility in maintenance. To accommodate multiple methods of using the virtual garden viewing interface, it is augmented by a Macromedia Flash panel that allows users to navigate the garden quickly using an overhead map. Additional features, 


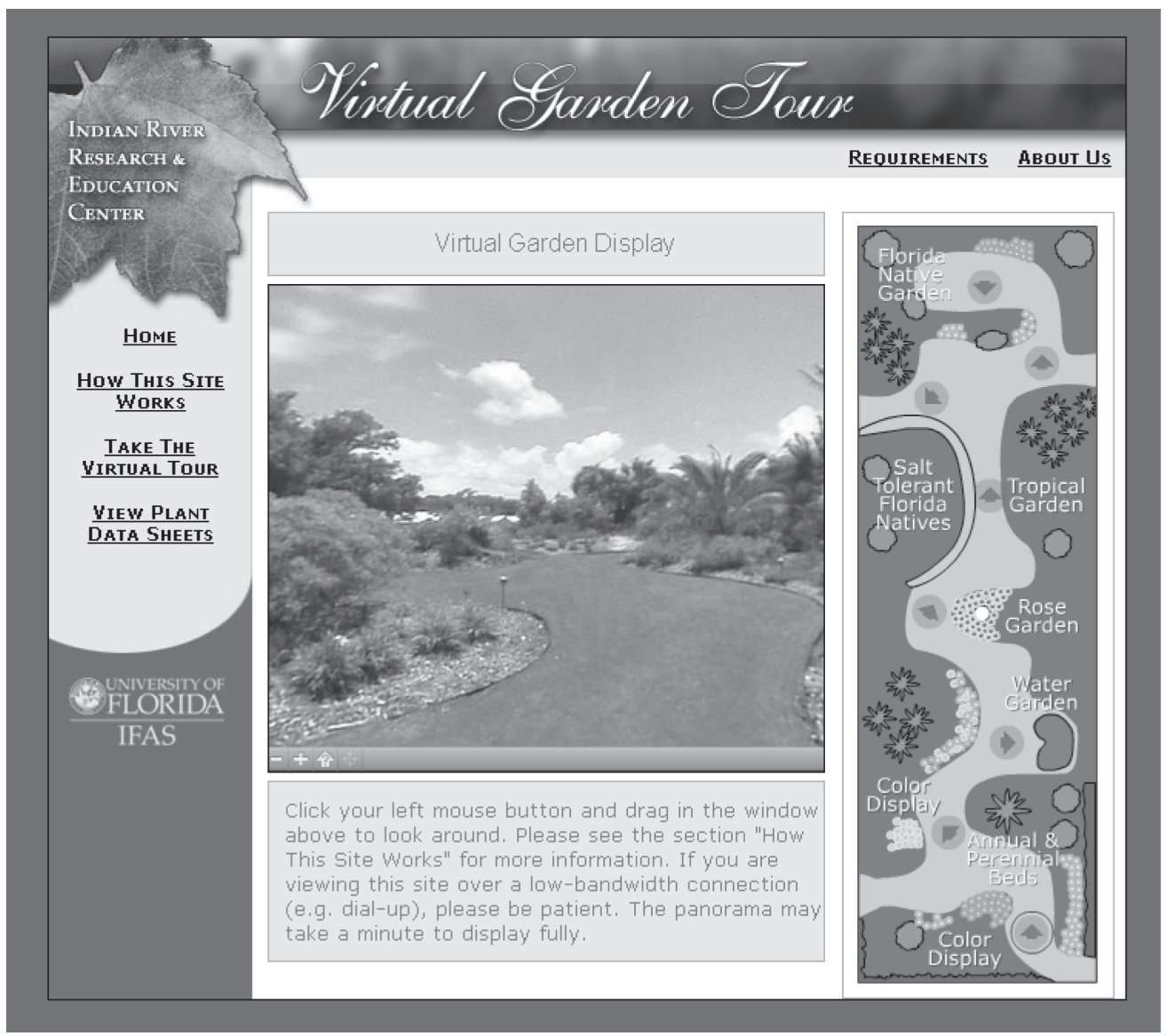

Fig. 1. Screen capture of the virtual garden tour website displaying the entrance to the garden and a navigational map (Wilson, 2004).

such as alternate input method navigation, appropriate textual contrast, and transitional and cascading style sheets, were implemented for optimal accessibility and standards compliance. Overall expenses associated with the initial design, development, and infrastructure of this project were estimated at $\$ 7500$ (labor), $\$ 1800$ (hardware), and $\$ 1600$ (software).

This interactive tool is among the first of its kind to engage students in virtual plant identification and use via web-based technology. Although the website initially was developed for a UF Florida native landscaping course (ORH 3815/5815C), it can be utilized in other plant identification and landscape courses by adding plant information sheets and hyper-linking them to the existing panorama. For educational purposes, copies of the plant information data sheets may be downloaded directly from the virtual tour panoramic website (Wilson, 2004).

\section{Literature cited}

Anderson, N.O. and J.D. Walker. 2003. Effectiveness of web-based versus live plant identification. HortTechnology 13:199-205.

Gilman, E.F. 1994. Using CD-Rom computer technology to teach plant materials. HortScience 29:461-462. (Abstr.)

Gómez, N. 2004. Is an instructional video better than a face-to-face demo to teach $\mathrm{t}$-budding in an intro plant propagation course? HortTechnology 14:619-621.

Kahtz, A.W. 2000. Can computer-assisted instruction be used by students for woody plant identification? HortTechnology 10:381-384.

Martin, C.A. and J.C. Stutz. 1999. Southwest home horticulture: Using video and the internet in the instruction of nonmajors. HortTechnology 9:495-497.

Murphy, T.H. 1996. Agricultural education and distance education: The time is now. Agr. Educ. Mag. 68(11):3, 22-23.

Sabota, C., C.A. Beyl, and G. Ghale. 1995. Developing an integrated location and information database for teaching plant identification and use. HortTechnology $5: 178-182$

Shaw, P.M. 1993. A low-cost interactive computer program for teaching landscape plant materials. HortTechnology 3:351-354.

Starrett, M.C. 2003. Virtual plant walks. 10 Jan. 2005. <http://www.hort.uconn. edu/plants/campus/vermont/vermont. html>.

Tignor, M.E. and S.B. Wilson. 1999. Sowing the seeds of a new horticulture sciences teaching program. Proc. Fla. State Hort. Soc. 112:255-260.

Wilson, S.B. 2004. Virtual garden tour. 9 Jan. 2005. <http://irrecenvhort.ifas.ufl. edu/virtualgarden/index.htm>.

Wilson, S.B. and M. Thetford. 2003. A new strategy for teaching plant propagation by distance education. HortTechnology 13:577-578.

Wilson, S.B. L.K. Mecca, and J.A. Gersony. 2004. Design, development and use of an ornamental teaching garden at the Indian River Research and Education Center, University of Florida. Acta Hort. 641:137-143. 